\title{
Aminothiazoles: Hit to Lead Development to Identify Antileishmanial Agents
}

Debnath Bhuniya $^{\mathrm{a}}$, Rao Mukkavilli ${ }^{\mathrm{a}}$, Rahul Shivahare ${ }^{\mathrm{b}}$, Delphine Launay ${ }^{\mathrm{c}}$, Ravindra T. Dere $^{\mathrm{a}}$, Anil Deshpande ${ }^{\mathrm{a}}$, Aditya Verma ${ }^{\mathrm{b}}$, Preeti Vishwakarma ${ }^{\mathrm{b}}$, Manjunath Moger ${ }^{\mathrm{a}}$, Ashok Pradhan ${ }^{\mathrm{a}}$, Hari Pati ${ }^{\mathrm{a}}$, Vadiraj S. Gopinath ${ }^{\mathrm{a}}$, Suman Gupta ${ }^{\mathrm{b} *}$, Sunil K. Puri ${ }^{\mathrm{b}}$, and Denis Martin ${ }^{\mathrm{c}}$

advinus Therapeutics Ltd. Bengaluru - 560 058, India, ' Division of Parasitology, CSIRCentral Drug Research Institute, Lucknow - 226 031, India, ' Drugs for Neglected Diseases initiative (DNDi), 15 Chemin Louis Dunant, 1202, Geneva, Switzerland

\section{*Corresponding Author}

Phone: +91 9415755899; Fax: +91 5222771941

E-mail: gupta_suman@yahoo.com or suman_gupta@cdri.res.in (Suman Gupta)

\begin{abstract}
As part of Drugs for Neglected Diseases initiative's lead optimization program for the development of new chemical entities to treat visceral leishmaniasis (VL), a series of aminothiazoles were synthesized and screened for in vitro efficacy, solubility and microsomal stability. The primary aim of identifying a lead structure with submicromolar activity was achieved. Out of 43 compounds synthesized, 16 compounds showed in vitro activity at less than $1 \mu \mathrm{M}$ against VL. Compound 32 showed excellent antileishmanial potency $\left(\mathrm{IC}_{50}=3 \mathrm{nM}\right)$ and had all the acceptable properties except for metabolic instability. Blocking the metabolic soft spots in compound 32, where the 4methoxy pyridine substituent was replaced by 5-ethoxy group, led to compound 36 ( IC $_{50}$ $=280 \mathrm{nM}$ ) with improved stability. To understand the disposition of 36, in vivo
\end{abstract}


pharmacokinetic study was conducted in a mouse model. Compound 36 showed high clearance $(91 \mathrm{~mL} / \mathrm{min} / \mathrm{kg})$; short half-life $(0.48 \mathrm{~h})$ after intravenous administration (1 $\mathrm{mg} / \mathrm{kg}$ ) and exposure $\left(\mathrm{AUC}_{0-24}\right)$ following oral administration was $362 \mathrm{ng} . \mathrm{h} / \mathrm{mL}$ with absolute bioavailability of $8 \%$. To summarize, 43 analogs were synthesized out of which 15 compounds showed very potent sub-nanomolar efficacy in in vitro systems but the liability of metabolic instability seemed to be the major challenge for this chemical class and remains to be addressed.

Keywords: Aminothiazoles; Visceral leishmaniasis; Leishmania donovani; Metabolic stability; Pharmacokinetics

\section{Introduction}

Neglected tropical diseases (NTDs) like visceral leishmaniasis (VL) represent the fourth most important communicable disease worldwide behind the respiratory infections, HIV/AIDS and diarrheal diseases. Tropical diseases like leishmaniasis affect the poor and powerless populations in rural and impoverished urban areas of developing countries and therefore are neglected from most drug development programs. Neglected tropical diseases are highly endemic with an ability to impair childhood growth (nearly one-half of the VL patients worldwide are children), intellectual development, as well as worker productivity $[1,2]$.

Ironically, only $4 \%$ of approved drugs (and 1\% of the new chemical entities approved) from 2000-2011 were for NTDs mainly due to low profitability margin for developers, poor health care policies and funding by governments, lack of drug discovery 
and development expertise [3]. To address the pressing need to develop drugs which are safe, affordable, easy to administer and efficacious, seven institutions from all over the world came together and founded in 2003 the Drugs for Neglected Diseases initiative (DNDi) in Geneva, Switzerland.

Leishmaniasis is a parasitic illness caused by haemoflagellate protozoans belonging to the genus Leishmania. Leishmania donovani is the most common agent causing VL [4]. VL manifests as fever, hepatosplenomegaly and pancytopenia. If untreated, it is always fatal. VL is endemic in large geographical areas around the globe affecting 88 countries. An estimated 200,000 to 400,000 new cases of VL are reported worldwide each year with 20,000 to 30,000 deaths [5]. Over 90\% of new cases are being reported from Bangladesh, Brazil, Ethiopia, India, Nepal and Sudan [6].

Currently, miltefosine is widely used as the only available oral drug for the treatment of VL but is teratogenetic, has a long half-life, low therapeutic window and early signs of resistance have recently been reported [7,8]. A low cost injectable paromomycin has been registered in India for VL treatment but it presents cytotoxicity and hepatotoxicity $[9,10]$. Amphotericin B is administered parenterally, but it is very toxic in addition to being costly, and is typically used as a second line of treatment when antimonials fail. The liposomal formulation of Amphotericin B, AmBisome ${ }^{\mathrm{TM}}$ is less toxic but is also costly and still requires hospitalization [11, 12].

The objective of DNDi was to develop an effective and safe oral drug that would cost less than $\$ 10$ per course. In order to achieve this ambitious aim, DNDi has put together a team to undertake screening and lead optimization activities on VL and other neglected diseases in its portfolio. 
The first ever high throughput screening (HTS) campaign against the intracellular form of $L$. donovani was completed at Institut Pasteur Korea (IPK) with a library of 200,000 compounds. From the hits identified, 10 scaffolds emerged and the one (aminothiazole) bearing the most appropriate drug-like features was selected for further optimization (Figure 1). The aminothiazoles, fused aminothiazoles, and other aminothiazoles linked to various heterocyclic rings have recently gained attention for their chemotherapeutic activity for treatment of malaria [13], prion disease [14], antiinflammatory/cancer [15] and tuberculosis [16].

The most active hits identified in the series were re-synthesized and their in vitro potency was confirmed in $L$. donovani amastigotes. Close analogs were then designed, synthesized and structure-activity relationships were established based on Lipinski and Veber rules (Table S1 and Figure S1, see in supporting information) [17, 18]. In addition to pharmacodynamic data, in vitro metabolism data in liver microsomes and mouse pharmacokinetic (PK) data helped the team in identifying leads with promising properties.

\section{Results and Discussion}

\subsection{Chemistry}

All analogs of compound 1 (best hit selected through HTS) (Figure 1) were synthesized using Scheme 1. Commercially available nitriles 2 were converted to acetophenones 3 by reacting with methyl magnesium bromide in THF at $0{ }^{\circ} \mathrm{C}$ over $2 \mathrm{~h}$ with $70-80 \%$ yield. Bromination of acetophenones 3 using $\mathrm{HBr}$ and bromine in acetic acid at $4-8{ }^{\circ} \mathrm{C}$ and further stirring at room temperature for $2 \mathrm{~h}$ afforded the corresponding a-bromoketones 4 with $90 \%$ yield. Substituted amines 5 were converted to the 
isothiocyanate intermediates by reacting with thiophosgene at ambient temperature, followed by reaction with ammonia gas at $0{ }^{\circ} \mathrm{C}$ over 10 min to give the corresponding thiourea $\mathbf{6}$ with $40-50 \%$ yield. Couplings of $\mathbf{4}$ with $\mathbf{6}$ were carried out under microwave irradiation in ethanol over $3 \mathrm{~min}$, the solid products 7-31 obtained were further isolated by filtration with yield consistently above 70\%. To a solution of compound 7-31 in DMF, $\mathrm{N}$-chlorosuccinimide was added at $0{ }^{\circ} \mathrm{C}$ and stirred at room temperature for $24 \mathrm{~h}$. The reaction mixture was diluted with water and extracted with ethyl acetate to give compounds 32-48 in 40-50\% yield.

\subsection{Biological Activity}

All the synthesized compounds were tested methodically in vitro against the intracellular form of $L$. donovani and their cytotoxicity and ADME properties assessed.

\subsubsection{First Results on Phenyl and Pyridine Analogs}

Table 1 shows the SAR results observed with a pyridine (Py) and phenyl (Ph) as A-ring (Ar) modification on compound $\mathbf{1}$. The in vitro screening results showed that pyridine ring substitution in most cases gives far better potency than the phenyl ring. We further investigated the position of the nitrogen in the pyridine ring and synthesized other analogs 16 \& 17. In A-ring, 2-pyridine was found to be optimal, and on closer examination of SAR, it was evident that electron-donating substituents like methyl and methoxy on B-ring were giving better potency (Table 1). Indeed, pyridine derivatives $\mathbf{1}$ $\left(\mathrm{IC}_{50}=3.6 \mu \mathrm{M}\right), 8\left(\mathrm{IC}_{50}=2.6 \mu \mathrm{M}\right), 9\left(\mathrm{IC}_{50}=2.6 \mu \mathrm{M}\right)$ showed better activity than all other compounds. It also seemed clear that the only suitable position of nitrogen in the Aring was 2-position. The 2-pyrimidine analog 18 of compound $\mathbf{8}$ was also synthesized and screened but resulted in loss of potency. Before proceeding to explore further SAR and to 
understand the behavior of the series, in vivo pharmacokinetics of compound 9 (50 $\mathrm{mg} / \mathrm{kg}$ ) was evaluated following oral gavage administration in male Swiss Albino mice. The pharmacokinetic parameters are summarized in Table 2. Following oral suspension administration of compound $\mathbf{9}$, the time to reach maximum plasma concentration $\left(\mathrm{T}_{\max }\right)$ was $0.25 \mathrm{~h}$. The concentration obtained at $\mathrm{T}_{\max }$ was at least 6-fold lower than the expected efficacious level $\left(\mathrm{IC}_{50}=670 \mathrm{ng} / \mathrm{mL}\right)$. Drug concentration was detected only till 3 hours post dose (Figure 2).

\subsubsection{Improved Potency by Substitution in the B-ring}

As compound 9 showed high in vivo clearance and the concentrations achieved were well below the desired $\mathrm{IC}_{50}$ value, further analogs 19-24 having different substitutions in the B-ring were synthesized, with A-ring being 2-pyridine, and evaluated against $L$. donovani amastigotes. Table 3 shows the SAR results observed with substitution in the phenyl B-ring. Compound 23 with a nanomolar potency $\left(\mathrm{IC}_{50}=370\right.$ nM) was identified (Figure 3).

\subsubsection{Influence of Pyridine instead of Phenyl ring as B-ring}

To further enhance the potency and expand the SAR, the phenyl ring (B-ring) of 9 was replaced with a pyridine or substituted pyridine ring and a series of analogs 25-31 were synthesized. Typically the increase in nitrogens in the structure makes the compound more hydrophilic. The potency results were very promising with almost all analogs showing nanomolar $\mathrm{IC}_{50}$ values, except for compound 25 (IC $_{50}=2.1 \mu \mathrm{M}$, Table 4). We were delighted to achieve targeted in vitro potency, however, none of the analogs had adequate metabolic stability as they were metabolized over $90 \%$ within $30 \mathrm{~min}$ of 
incubation with hamster and mouse liver microsomes (Table 4), even when pyridine as B-ring was substituted to reduce its metabolism.

To address the issue of metabolic instability of compounds in microsomes, we chose the most potent analog $30\left(\mathrm{IC}_{50}=90 \mathrm{nM}\right.$, Figure 4) and blocked the potential metabolic hot spots with methoxy, ethoxy and trifluromethyl substitutions in the A-ring 32-35. Once again, potency was retained but none of the compounds were metabolically stable (Table 5). Compound 32 (Figure 5) showed an $\mathrm{IC}_{50}$ of $3 \mathrm{nM}$ and was completely metabolized in hamster and mouse liver microsomes within 30 min. Even the trifluoromethyl-substituted compound 35 ( $\mathrm{IC}_{50}=0.54 \mu \mathrm{M}$, Figure 5) was unstable in the tested microsomes (Table 5). Compound 36 showed an $\mathrm{IC}_{50}$ of $0.28 \mu \mathrm{M}$ and appeared stable in hamster with $10 \%$ metabolism and $62 \%$ in mouse liver microsomes in $30 \mathrm{~min}$.

Based on the in vitro potency and microsomal stability data, the pharmacokinetics of compound 36 were evaluated following intravenous bolus administration $(1 \mathrm{mg} / \mathrm{kg}$; solution) and oral gavage administration (25 mg/kg; suspension) in male Swiss Albino mice (Table 7). Compound 36 showed high plasma clearance (CL, $91 \mathrm{~mL} / \mathrm{min} / \mathrm{kg}$, equivalent to normal liver blood flow of $90 \mathrm{~mL} / \mathrm{min} / \mathrm{kg}$ ). The volume of distribution (Vss, $1.99 \mathrm{~L} / \mathrm{kg})$ was 3 -fold higher total body water $(0.7 \mathrm{~L} / \mathrm{kg})$ and elimination half-life $\left(\mathrm{T}_{1 / 2}\right)$ was low $0.48 \mathrm{~h}$. Following oral solution administration of $\mathbf{3 6}$, the time to reach maximum plasma concentration $\left(\mathrm{T}_{\max }\right)$ was observed at $0.25 \mathrm{~h}$ confirming rapid absorption with absolute bioavailability (F) of 8\% (Figure 6). Plasma protein binding of compound 36 was assessed in mouse plasma by equilibrium dialysis, which was found to be very highly bound to plasma proteins (99.64\%). 


\subsubsection{Addressing Metabolic Stability Issues by Substitutions in the Thiazole Ring}

As different substitutions in the A-ring did not yield desirable metabolic stability, we focused our effort on thiazole ring. In addition to blocking the metabolic soft spots in A-ring, the carbon next to sulphur was substituted with chloro group and compounds 3741 were synthesized. No real improvement in metabolic stability of compounds was observed in this subseries, although, most of the compounds retained potency (Table 6). One exception was compound $\mathbf{4 0}$ which appeared significantly stable (\% metabolism in 30 min: HamLM = 63, MLM = 30) compared to other analogs, but unfortunately in vitro potency was lost $\left(\mathrm{IC}_{50}=4.23 \mu \mathrm{M}\right)$.

\subsubsection{Influence of Nitrogen Containing Heterocycles Other Than Pyridine as A-Ring}

\section{Substituents}

In order to understand the influence of nitrogen heterocycles other than pyridine as A-ring on potency and metabolic stability, compounds 42-48 were synthesized and assessed (Table 8). None of the compounds synthesized showed desired activity. Compound 47 only showed a marginal improvement in metabolic stability. From this series it was evident that nitrogen functionality in the A-ring at 2 and 6-position would yield compounds with good efficacy. Protection of the remaining spots may lead to metabolically stable analogs.

2.3 Analysis of Physicochemical Properties using Lipinski's Rule of Five and Veber Rules

Lipinski and Veber proposed guidelines for drug development based on the structural properties of compounds like molecular weight, cLog P, hydrogen bond donors/acceptors and polar surface area. Structural properties in turn are responsible for 
physicochemical properties like solubility and permeability and biochemical properties like metabolism and excretion. If solubility and permeability of compounds are high and can be classified as Class I compound as per the biopharmaceutical classification system (BCS), then the likelihood of a compound's development is high.

All compounds synthesized by us had molecular weights less than 500 , calculated Log P values were less than 5, and the number of hydrogen bond donors and acceptors were less than 5 and 10, respectively. As per Veber rules, none of the compounds had more than 12 hydrogen bond donors and acceptors, PSA was less than $140 \AA^{2}$ and less than 10 rotatable bonds (single bond, not in ring, bound to non-hydrogen atom, non C-N bonds). None of the compounds synthesized had a chiral center except for compound $\mathbf{4 8 .}$ With increase in lipophilicity, the polar surface area was more or less similar and less than $140 \AA$ for all the analogs suggesting good absorption in vivo. Around $60 \%$ of the compounds synthesized had efficacy $\mathrm{IC}_{50}$ values below $5 \mu \mathrm{M}$ with corresponding cLog P values between 3 and 5 . Around $20 \%$ of the compounds with similar cLog P values showed $\mathrm{IC}_{50}$ values above $100 \mu \mathrm{M}$. To summarize, based on $\operatorname{cLogP}$ and other physicochemical parameters, no definitive structure activity relationship was apparent.

\section{Conclusion}

Despite the tenacious efforts in the last decade in identifying leads for neglected diseases, a persistent gap still remains. Of the four NCEs that have been developed for neglected diseases, three were for malaria and one for cryptosporidiosis. For VL, two repurposed or reformulated versions of miltefosine and paromomycin were approved [3]. There have been two major challenges in identifying novel leads for VL: (1) difficulty in accessing high quality hits from screening of libraries and (2) the lack of a well-defined 
screening cascade for various stages of discovery and development, and the need for better understanding of the ADME properties of lead compounds, as well as correlation with pharmacodynamic data. In this paper, we have explored the aminothiazole hits that seem to be recurrent in many screening campaigns for VL. We successfully synthesized a range of diverse analogs and drew interesting exploratory structure-activity relationships with these aminothiazole compounds. Potent analogs were obtained with in vitro $\mathrm{IC}_{50}$ as low as $3 \mathrm{nM}$ but metabolic instability of this series needs to be addressed to obtain in vivo efficacious compound. However, impressed with excellent in vitro activity against the intracellular form of $L$. donovani, ease of synthesis, and armed with the understanding of SAR, the team is considering synthesizing aminothiazoles analogs for further assessment.

\section{Experimental Section}

\subsection{General Methods}

4.1.1. Representative Procedure for the Synthesis of Compound 3. To a solution of compound 2 (1 equivalent) in dry THF under $\mathrm{N}_{2}$ atmosphere, $3 \mathrm{M}$ solution of methyl magnesium bromide (2 equivalent) was added drop wise at $0{ }^{\circ} \mathrm{C}$ and the reaction was stirred for $1-2 \mathrm{~h}$ at the same temperature. To the resulting reaction mixture aqueous ammonium chloride solution was added and the organic layer was separated out. The aqueous layer was extracted with ethyl acetate twice and the combined organic layer was washed with brine solution, dried over $\mathrm{Na}_{2} \mathrm{SO}_{4}$ and concentrated under reduced pressure. The residue was purified by silica gel column chromatography using ethyl acetate: hexane as eluent with a yield of $70-80 \%$.

4.1.2. Representative Procedure for the Synthesis of Compound 4. To a solution of compound 3 (1 equivalent) in glacial acetic acid (10 volumes), $\mathrm{HBr}$ in acetic acid (33\%, 5 
volumes) was added and cooled to $0{ }^{\circ} \mathrm{C}$. Then $\mathrm{Br}_{2}$ (1.2 equivalent) dissolved in acetic acid (1 volume) by adding drop wise. After addition the reaction mixture was warmed to $30{ }^{\circ} \mathrm{C}$ and stirred for 1-2 h. The resulting slurry was filtered off and the filter cake was washed with diethyl ether (3 volumes). The product was dried in vacuum and isolated as $\mathrm{HBr}$ salt with a yield of $80-90 \%$.

4.1.3. Representative Procedure for the Synthesis of Compound 6. To the solution of compound 5 (1 equivalent) in DCM, $\mathrm{NaOH}$ (3.5 equivalent) was added and cooled to 0 ${ }^{\circ} \mathrm{C}$. Then thiophosgene (3 equivalents) was added drop wise and the reaction was stirred for $1 \mathrm{~h}$ to $5 \mathrm{~h}$ at $30^{\circ} \mathrm{C}$. The reaction mixture was quenched with water and extracted with DCM twice. The combined organic layer was washed with brine, dried over $\mathrm{Na}_{2} \mathrm{SO}_{4}$ and concentrated under reduced pressure to afford isothiocyanate intermediate. This isothiocyanate intermediate was dissolved in DCM, cooled to $0{ }^{\circ} \mathrm{C}$, and ammonia gas purged for $10 \mathrm{~min}$. The resulting solid product was filtered off, dried in vacuum to afford substituted thiourea with a yield of $40-50 \%$.

4.1.4. Representative Procedure for the Synthesis of Compound 7-31. Compounds 4 (1 equivalent) and 6 (1 equivalent) were dissolved in EtOH (2 volumes). The reaction mixture was irradiated with microwave for $3 \mathrm{~min}$. After completion of the reaction, it was cooled to room temperature. The solid precipitate was filtered off. The filter cake was stirred with $10 \%$ sodium bicarbonate and sodium thiosulfate solution for $30 \mathrm{~min}$. The solid obtained was filtered and dried at vacuum to afford compounds 7-31 with a good yield of $70-80 \%$.

4.1.5. Representative Procedure for the Synthesis of Compound 32-48. To a solution of compound 7-31 (1 equivalent) in DMF, $\mathrm{N}$-chlorosuccinimide (1 equivalent) at $0{ }^{\circ} \mathrm{C}$ was 
added and stirred at $30{ }^{\circ} \mathrm{C}$ for $12 \mathrm{~h}$ to $24 \mathrm{~h}$. The reaction mixture was diluted with water (10 volumes) and extracted with ethyl acetate thrice. The combined organic layer was washed with brine, dried over $\mathrm{Na}_{2} \mathrm{SO}_{4}$ and concentrated under reduced pressure. The crude product was purified by preparative HPLC using acetonitrile and water as eluent and ammonium formate as buffer solution to afford compound 32-48 with a yield of 40$50 \%$.

\subsection{Lipinski's Rule of Five and Veber Rules}

ChemDraw Ultra 10, Cambridgesoft was used to draw the structures and calculate the physicochemical parameters.

\subsection{Experimental Section for Biology}

\subsubsection{Animal Husbandry and Handling}

All animal pharmacokinetic studies described were performed with the approval of the Institutional Animal Ethics Committee of Advinus Therapeutics Limited and in accordance with the guidelines of the CPCSEA, Government of India. Animals were acclimatized in study room for at least three days prior to dosing. During the course of the study, mice were housed in polypropylene cages with three animals per cage suitably marked with turmeric for identification. Animals used in the studies were bred in-house. Good quality water passed through activated charcoal filter and exposed to UV rays was provided ad libitum throughout the study periods. Mice received Nutrilab ${ }^{\circledR}$ rodent pellet food (manufactured by Tetragon Chemie Pvt. Ltd., India) ad libitum except on the day of dosing ( $4 \mathrm{~h}$ before dosing feed was removed and provided $4 \mathrm{~h}$ post dose). The temperature and humidity of the experimental rooms were maintained between $22 \pm 3{ }^{\circ} \mathrm{C}$ 
and 40 to $70 \%$, respectively with approximately 10-15 fresh air cycle per hour and 12 hours fluorescent light and 12 hours dark photoperiod.

\subsubsection{In vitro Antiamastigote Activity}

For assessing the activity of compounds against the amastigote stage of the parasite, mouse macrophage cell line (J-774A.1) infected with promastigotes (strain: MHOM/IN/80/Dd8) expressing luciferase firefly reporter gene was used [19]. Cells were seeded in a 96-well plate $\left(4 \times 10^{3}\right.$ cells/100 $\mu \mathrm{L} /$ well $)$ in RPMI-1640 medium containing $10 \%$ heat inactivated fetal calf serum and the plates were incubated at $37^{\circ} \mathrm{C}$ in a $\mathrm{CO}_{2}$ incubator. After the incubation, medium was replaced with fresh medium containing stationary phase promastigotes $\left(4 \times 10^{4} / 100 \mu \mathrm{L} /\right.$ well $)(1: 10$ ratio of macrophage: parasite). Promastigotes invade the macrophage and are transformed into amastigotes. After $24 \mathrm{~h}$ incubation, each well of the plate was washed with plain RPMI medium to remove the un-internalized promastigotes. The test compounds (starting from $100 \mu \mathrm{M}$ ) in fresh RPMI-1640 medium was added after replacing the previous medium and the plates were incubated at $37{ }^{\circ} \mathrm{C}$ in a $\mathrm{CO}_{2}$ incubator for $72 \mathrm{~h}$. After incubation, the drug containing medium was aspirated and $50 \mu \mathrm{L}$ PBS was added in each well and mixed with an equal volume of Steady Glo reagent. After gentle shaking for $3 \mathrm{~min}$, the reading was taken in a luminometer and expressed as relative luminescence units (RLU) [20]. Data were plotted using Excel software and $\mathrm{IC}_{50}$ values of antileishmanial activity were calculated by nonlinear regression analysis of the concentration response curve using the four parameters Hill equation. 


\subsubsection{Cytotoxicity Assay}

The cell viability was determined using the MTT (3- (4, 5-Dimethylthiazol-2-yl)2, 5-diphenyltetrazolium bromide, a yellow tetrazole) assay [21]. Exponentially growing cells (KB Cell line, $1 \times 10^{5}$ cells/100 $\mu \mathrm{L} /$ well) were incubated with test compounds for $72 \mathrm{~h}$. The test compounds were added at three fold dilutions up to 7 points in complete medium starting from $400 \mu \mathrm{M}$, and were incubated at $37^{\circ} \mathrm{C}$ in a humidified mixture of $5 \% \mathrm{CO}_{2}$ in an incubator. Podophyllotoxin was used as a reference drug and control wells containing dimethyl sulfoxide (DMSO) without compounds were also included in the experiment. Stock solutions of compounds were initially prepared in DMSO and further diluted with fresh complete medium. After incubation, $25 \mu \mathrm{L}$ of MTT reagent $(5 \mathrm{mg} / \mathrm{mL})$ in PBS medium was added to each well and incubated at $37^{\circ} \mathrm{C}$ for $2 \mathrm{~h}$. At the end of the incubation period, the supernatant was removed by inverting the plate completely without disturbing the cell layer and $150 \mu \mathrm{L}$ of pure DMSO was added to each well. After 15 min of shaking, the readings were recorded at wavelength maxima of $544 \mathrm{~nm}$ on a micro plate reader [22]. The cytotoxic effect was expressed as $50 \%$ lethal dose $\left(\mathrm{CC}_{50}\right)$, i.e., as the concentration of a compound which reduced $50 \%$ of cell viability compared to cell in culture medium alone. $\mathrm{CC}_{50}$ values were estimated as described by Huber and Koella [23]. The selectivity index (SI) for each compound was calculated as ratio between, cytotoxicity $\left(\mathrm{CC}_{50}\right)$ in $\mathrm{KB}$ cells and activity $\left(\mathrm{IC}_{50}\right)$ against Leishmania amastigotes.

\subsubsection{Solubility Assay}

The study was performed in a 96-deep well plate by spiking $10 \mu \mathrm{L}$ of working stock dilutions $(1,2,4,6,8$, and $10 \mathrm{mM}, \mathrm{n}=2)$ prepared in DMSO to $990 \mu \mathrm{L}$ of sodium phosphate buffer (50 mM, pH 7.4). Spiked buffer samples were maintained at room 
temperature for $2 \mathrm{~h}$. The plate was centrifuged at $1700 \mathrm{~g}$ for $20 \mathrm{~min}$ at room temperature to enable the insoluble particles/precipitates to settle down. The centrifuged samples were diluted 1:1 with acetonitrile and analyzed using UV spectrometry at wavelength maxima. The calibration curve standards were prepared by spiking $5 \mu \mathrm{L}$ of working stock solutions into $995 \mu \mathrm{L}$ of acetonitrile-buffer mixture. Acetonitrile-buffer-DMSO mixture was used as blank sample. The solubility in buffer was calculated by using the following equation:

$\%$ Nominal $=\frac{\text { Mean of calculated concentration of test samples }}{\text { Calculated concentration of calibration curve }} \times 100$

\subsubsection{Microsomal Stability Assay}

Liver microsomes $(0.5 \mathrm{mg} / \mathrm{mL}$ male golden Syrian hamster and male CD-1 mouse, Xenotech LLC, Kansas, USA), NADPH (2 mM) and phosphate buffer (50 mM; $\mathrm{pH}$ 7.4) were mixed in microfuge tubes and pre-incubated in an orbital shaker for $10 \mathrm{~min}$ at $37^{\circ} \mathrm{C}$. The reactions were initiated by addition of compound stock solution to produce $0.5 \mu \mathrm{M}$ final concentration (5 $\mu \mathrm{L}, 100 \mu \mathrm{M}$, ACN:DMSO: 96:4). Aliquots (50 $\mu \mathrm{L}$ ) were withdrawn at $0,3,6,9,12,15,18,27$ and $30 \mathrm{~min}$ and quenched with acetonitrile (50 $\mu \mathrm{L}$ ) containing internal standard; the samples were analyzed for parent compound. Concomitant NADPH-free control incubations were prepared similarly with samples collected at $0 \mathrm{~min}$ and $30 \mathrm{~min}$. The percent metabolized for test compound in each sample was determined by considering peak area ratio in the 0 min sample as $100 \%$ [20].

\subsubsection{Plasma Protein Binding Assay}

Mouse plasma collected using $\mathrm{K}_{2}$ EDTA (20 $\mu \mathrm{L}$ per $\mathrm{mL}$ of blood, $200 \mathrm{mM}$ ) as anticoagulant was used for the experiments. Aliquots of plasma (1992 $\mu \mathrm{L})$ were spiked with $8 \mu \mathrm{L}$ of test compound stock solution ( $2.5 \mathrm{mM}$ ) to produce $10 \mu \mathrm{M}$. Following gentle 
inversion, a sample (120 $\mu \mathrm{L})$ was collected immediately ( $\mathrm{t}=0 \mathrm{~min})$ to determine spiking accuracy, and similar samples were collected into microfuge tubes and incubated for $6 \mathrm{~h}$ at $37^{\circ} \mathrm{C}$ in order to establish stability under conditions similar to the dialysis conditions. The remaining spiked plasma was used to load into the equilibrium dialysis cells. Prior to loading plasma and buffer into the dialysis cells, the cells were assembled with presoaked dialysis membranes and the dialysis cells were clamped tight. For each replicate, $120 \mu \mathrm{L}$ of test compound spiked plasma was placed into one half-cell (donor compartment) and $120 \mu \mathrm{L}$ of blank buffer into the other half-cell (receiver compartment). The dialyzer apparatus was placed in a $5 \% \mathrm{CO}_{2}$ incubator shaker maintained at $37^{\circ} \mathrm{C}, 120 \mathrm{rpm}$ for $6 \mathrm{~h}$. After 6 h, plasma and buffer samples were separately recovered from each half-cell and quantified by using LC/MS/MS.

\subsubsection{Bioanalysis of In vitro Samples}

Samples from in vitro studies were analyzed for parent drug using acetonitrile precipitation and analyzed by employing positive-ion electron spray ionization mode in liquid chromatography tandem mass spectrometry (API4000, Applied Biosystems, USA). Samples from microsomal stability studies were analyzed for peak area ratios. Samples from studies of plasma protein binding were quantitatively analyzed for parent compound by LC-MS/MS using a mixed matrix of $5 \mu \mathrm{L}$ of DMSO (stock solution or blank), $5 \mu \mathrm{L}$ plasma and $50 \mu \mathrm{L}$ buffer. An isocratic method with 5 min run time was employed for analysis. The mobile phase consisted of $5 \mathrm{mM}$ ammonium formate and acetonitrile mixed in (40:60) with $0.05 \%$ formic acid. The separation of the analyte and internal standard (a structural analog) was achieved using BDS Hypersil C18 (4.6 x 100 mm, $5 \mu$ ) column (Grace, Discovery Sciences, USA). A flow rate of 0.6 to $1 \mathrm{~mL} / \mathrm{min}$ was maintained using 
Shimadzu Prominence solvent delivery system (LC-20AD). The mobile phase was degassed using degasser (DGU-20A $\mathrm{A}_{3}$ ), samples were loaded into autosampler (SIL-HT ${ }_{\mathrm{c}}$ ) and column oven (CTO-20A) maintained the temperature of column at $40{ }^{\circ} \mathrm{C}$. An injection volume of $2 \mu \mathrm{L}$ to $10 \mu \mathrm{L}$ was employed for sample analysis. The fraction unbound and fraction bound were calculated for each sample using the following equations:

$$
\begin{gathered}
\% \text { Unbound }=\left\{\frac{[\text { compound }]_{\text {receiver }}}{[\text { compound }]_{\text {donor }}}\right\} \times 100 \% \\
\% \text { Bound }=100 \%-\% \text { Unbound }
\end{gathered}
$$

Where $[\text { compound }]_{\text {receiver }}=$ concentration of test compound in the buffer following dialysis and $[\text { compound }]_{\text {donor }}=$ concentration of test compound in plasma samples following dialysis.

\subsubsection{In vivo Pharmacokinetic Studies}

Studies were performed in healthy male Swiss Albino mice (30-40 g, 8-12 weeks age). A sparse sampling design was used in mice ( $\mathrm{n}=3$ per time point) with samples drawn at 0.083 (IV), $0.25,0.5,1,3,6,8,10$, and $24 \mathrm{~h}$. Blood samples were collected in microfuge tubes containing $\mathrm{K}_{2}$ EDTA ( $20 \mu \mathrm{L}$ of $200 \mathrm{mM}$ per mL blood) and plasma was harvested by centrifugation at $2500 \mathrm{~g}$ for $5 \mathrm{~min}$. The supernatant was stored below $-60{ }^{\circ} \mathrm{C}$ until analysis.

\subsubsection{Bioanalysis}

Samples were processed by protein precipitation using acetonitrile with a suitable internal standard and analyzed by employing LC-MS/MS positive-ion electron spray ionization (API4000, Applied Biosystems, USA). The lower limit of quantification was $0.95 \mathrm{ng} / \mathrm{mL}$ and $5.08 \mathrm{ng} / \mathrm{mL}$ for compound 9 and compound 36, respectively. An 
isocratic method with 4 min run time was employed for analysis. The mobile phase consisted of $5 \mathrm{mM}$ ammonium acetate and acetonitrile (20:80 ratio for compound 9; 30:70 ratio for compound 36). The separation of the compound $\mathbf{9}$ and internal standard (a structural analog) was achieved using Discovery C18 (4.6 x $50 \mathrm{~mm}, 5 \mu$, Thermo, USA) and for compound 36 Kromasil C8 (4.6 x 50 mm, $5 \mu$, Grace, Discovery Sciences, USA) was used. A flow rate of $1 \mathrm{~mL} / \mathrm{min}$ was maintained using Shimadzu Prominence solvent delivery system (LC-20AD). The mobile phase was degassed using degasser (DGU$20 \mathrm{~A}_{3}$ ), samples were loaded into autosampler (SIL-HT $\mathrm{T}_{\mathrm{c}}$ ) and column oven (CTO-20A) maintained the temperature of column at $40^{\circ} \mathrm{C}$. An injection volume of $2 \mu \mathrm{L}$ to $10 \mu \mathrm{L}$ was employed for sample analysis.

\subsubsection{Pharmacokinetic Analysis}

Pharmacokinetic parameters were calculated using the non-compartmental analysis tool of validated WinNonlin ${ }^{\circledR}$ software (Version 5.2). The area under the concentration time curve $\left(\mathrm{AUC}_{\text {last }}\right.$ and $\left.\mathrm{AUC}_{\mathrm{inf}}\right)$ was calculated by linear trapezoidal rule. Peak concentration $\left(\mathrm{C}_{\max }\right)$ and time for the peak concentration $\left(\mathrm{T}_{\max }\right)$ were the observed values. Following intravenous administration, the clearance (CL) and volume of distribution (Vss) were estimated. The elimination rate constant value (k) was obtained by linear regression of the log-linear terminal phase of the concentration-time profile using at least 3 declining concentrations in terminal phase with a correlation coefficient of $>0.8$. The terminal half-life value $\left(T_{1 / 2}\right)$ was calculated using the equation $\ln 2 / k$.

\section{Acknowledgments}

This work was supported by the Drug for Neglected Disease initiative (DNDi). Specific funding from Bill \& Melinda Gates Foundation, USA, with complementary core 
funding from Department for International Development (DFID), UK; Dutch Ministry of Foreign Affairs (DGIS), Netherlands; Federal Ministry of Education and Research (BMBF) through KfW / Germany and part of the EDCTP2 program supported by the European Union; and Médecins Sans Frontières (Doctors Without Borders), International.

The authors thank Director, CSIR-Central Drug Research Institute, Lucknow, India. The transgenic $L$. donovani promastigotes were originally procured from Dr. Neena Goyal, Division of Biochemistry, CSIR-Central Drug Research Institute, Lucknow, India.

\section{Appendix. Supporting Information}

Supplementary data associated with this article (final compounds characterization data, NMR spectra of selected aminothiazoles, and physicochemical properties of compounds using Lipinski's rule of five and Veber rules criteria) can be found in the online version at doi:

\section{References}

[1] P.J. Hotez, D.H. Molyneu, A. Fenwick, E. Ottersen, S.E. Sachs, J.D. Sachs, Incorporating a rapid impact package for neglected tropical diseases with programs for HIV/AIDS, tuberculosis and malaria, PLoS Med. 3 (2006) e277.

[2] S.K. Bhattacharya, D. Sur, J. Karbwang, Childhood visceral leishmaniasis, Indian J. Med. Res.123 (2006) 353-356. 
[3] B. Pedrique, N. Strub-Wourgaft, C. Some, P. Olliaro, P. Trouiller, N. Ford, B. Pecoul, J.H. Bradol, The drug and vaccine landscape for neglected diseases (2000-11): a systemic assessment, Lancet Glob. Health 1 (2013) e371-e379

[4] P. Desjeux, Leishmaniasis: current situation and new perspectives, Comp. Immunol. Microbiol. Infect. Dis. 27 (2004) 305-318.

[5] Leishmaniasis. http://www.who.int/mediacentre/factsheets/fs375/en/

[6] F. Chappuis, S. Sundar, A. Hailu, H. Ghalib, S. Rijal, R. W. Peeling, J. Alvar and M. Boelaert, Visceral leishmaniasis: what are the needs for diagnosis, treatment and control? Nat. Rev. Microbiol. 5 (2007) 873-882.

[7] T.K. Jha, Drug unresponsiveness \& combination therapy for kala-azar, Indian J. Med. Res. 123 (2006) 389-398.

[8] S. Sundar, T.K. Jha, C.P. Thakur, J. Engel, H. Sindermann, C. Fischer, K. Junge, A. Bryceson, J. Berman, Oral miltefosine for Indian visceral leishmaniasis, $N$. Engl. J. Med. 347 (2002) 1739-1746.

[9] S. Sundar, T.K. Jha, C.P. Thakur, P.K. Sinha, S.K. Bhattacharya, Injectable paromomycin for visceral leishmaniasis in India, N. Engl. J. Med. 356 (2007) 2571-2581.

[10] L.H. Freitas-Junior, E. Chatelain, H.A. Kim, J.L. Siqueira-Neto, Visceral leishmaniasis treatment: What do we have, what do we need and how to deliver it? Int. J. Parasitol. Drugs. Drug. Resist. 2 (2012) 11-19.

[11] S.L. Croft, K. Seifert, V. Yardley, Current scenario of drug development for leishmaniasis, Indian J. Med. Res. 123 (2006) 399-410. 
[12] E. Chatelain, J.R. Ioset, Drug discovery and development for neglected diseases: the DNDi model, Drug Des. Devel. Ther. 5 (2011) 175-181.

[13] T. Paquet, R. Gordon, D. Waterson, M.J. Witty, K. Chibale, Antimalarial aminothiazoles and aminopyridines from phenotypic whole-cell screening of a SoftFocus((R)) library, Future Med. Chem. 4 (2012) 2265-2277.

[14] A. Gallardo-Godoy, J. Gever, K.L. Fife, B.M. Silber, S.B. Prusiner, A.R. Renslo, 2-Aminothiazoles as therapeutic leads for prion diseases, J. Med. Chem. 54 (2011) 1010-1021.

[15] T. Hanke, F. Dehm, S. Liening, S.D. Popella, J. Maczewsky, M. Pillong, J. Kunze, C. Weinigel, D. Barz, A. Kaiser, M. Wurglics, M. Lammerhofer, G. Schneider, L. Sautebin, M. Schubert-Zsilavecz, O. Werz, Aminothiazole-featured pirinixic acid derivatives as dual 5-lipoxygenase and microsomal prostaglandin E2 synthase-1 inhibitors with improved potency and efficiency in vivo, J. Med. Chem. 56 (2013) 9031-9044.

[16] A. Meissner, H.I. Boshoff, M. Vasan, B.P. Duckworth, C.E. Barry, C. E., C.C. Aldrich, Structure-activity relationships of 2-aminothiazoles effective against Mycobacterium tuberculosis, Bioorg. Med. Chem. 21 (2013) 6385-6397.

[17] C.A. Lipinski, F. Lombardo, B.W. Dominy, P.J. Feeney, Experimental and computational approaches to estimate solubility and permeability in drug discovery and development settings, Adv. Drug Deliv. Rev. 46 (2001) 3-26.

[18] D.F. Veber, S.R. Johnson, H.Y. Cheng, B.R. Smith, K.W. Ward, K.D. Kopple, Molecular properties that influence the oral bioavailability of drug candidates, $J$. Med. Chem. 45 (2002) 2615-2623. 
[19] Ashutosh, S. Gupta, Ramesh, S. Sundar, N. Goyal, Use of Leishmania donovani field isolates expressing the luciferase reporter gene in in vitro drug screening, Antimicrob. Agents. Chemother. 49 (2005) 3776-3783.

[20] V.S. Gopinath, J. Pinjari, R.T. Dere, A. Verma, P. Vishwakarma, R. Shivahare, M. Moger, P.S. Kumar Goud, V. Ramanathan, P. Bose, M.V. Rao, S. Gupta, S.K. Puri, D. Launay, D. Martin, Design, synthesis and biological evaluation of 2substituted quinolines as potential antileishmanial agents, Eur. J. Med. Chem. 69 (2013) 527-536.

[21] T. Mosmann, Rapid colorimetric assay for cellular growth and survival: application to proliferation and cytotoxicity assays, J. Immunol. Methods 65 (1983) 55-63.

[22] R. Shivahare, V. Korthikunta, H. Chandasana, M.K. Suthar, P. Agnihotri, P. Vishwakarma, T.K. Chaitanya, P. Kancharla, T. Khaliq, S. Gupta, R.S. Bhatta, J.V. Pratap, J.K. Saxena, S. Gupta, N. Tadigoppula, Synthesis, structure-activity relationships, and biological studies of chromenochalcones as potential antileishmanial agents, J. Med. Chem. 57 (2014) 3342-3357.

[23] W. Huber, J.C. Koella, A comparison of three methods of estimating EC50 in studies of drug resistance of malaria parasites, Acta Trop. 55 (1993) 257-261. 


\section{Figure Captions}

Table 1: First results on Phenyl and Pyridine analogs

Table 2: Pharmacokinetic parameters of compound 9 in male Swiss Albino mice following oral administration

Table 3: Influence of substituent on Phenyl B-ring

Table 4: Substituents on Pyridine Ring

Table 5: Influence of substituents on Pyridine Ring

Table 6: Modifications on the Thiazole Ring

Table 7: Pharmacokinetics parameters of compound 36 in male Swiss Albino mice following intravenous and oral gavage administration

Table 8: A-Ring: influence of nitrogen containing heterocycles other than Pyridine

Figure 1: Main subseries - Aminothiazoles (Hit 1)

Figure 2: Mean plasma concentration-time profile of compound 9 in male Swiss Albino mouse ( $\mathrm{n}=3$ per time point) following oral gavage $(50 \mathrm{mg} / \mathrm{kg})$ administration

Figure 3: Influence of substituent on Phenyl B-ring

Figure 4: Addressing metabolic instability by various substitutions in the Pyridine ARing

Figure 5: Lead compounds 32 and 36

Figure 6: Mean plasma concentration-time profile of compound 36 in male Swiss Albino mouse ( $\mathrm{n}=3$ per time point) following intravenous bolus (1 mg/kg) and oral gavage (25 $\mathrm{mg} / \mathrm{kg}$ ) administration

Scheme 1: Synthesis of Aminothiazole analogs to Hit 1 
Table 1:

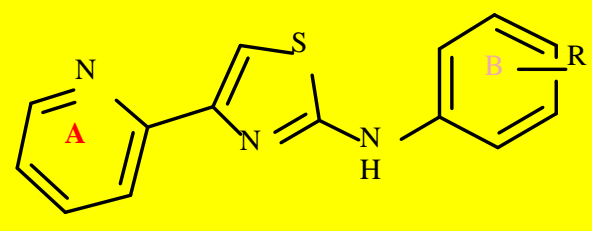

\begin{tabular}{|c|c|c|c|c|c|c|c|}
\hline \multirow{2}{*}{ Compd. } & \multirow{2}{*}{ Chemistry } & \multirow{2}{*}{$\begin{array}{l}\mathrm{IC}_{50}{ }^{\mathrm{a}} \\
(\mu \mathrm{M})\end{array}$} & \multirow{2}{*}{$\begin{array}{l}\mathrm{CC}_{50}{ }^{\mathrm{b}} \\
(\mu \mathrm{M})\end{array}$} & \multirow{2}{*}{$\mathrm{SI}^{\mathrm{c}}$} & \multirow{2}{*}{$\begin{array}{l}\text { Solubility } \\
\qquad(\mu \mathrm{M})\end{array}$} & \multicolumn{2}{|c|}{ Metabolic Stability } \\
\hline & & & & & & HamLM $^{\mathrm{e}}$ & MLM $^{\mathbf{f}}$ \\
\hline 1 & & 3.6 & 54.4 & 15 & 20 & 100 & 100 \\
\hline 7 & & $>100$ & $\mathrm{ND}^{\mathrm{g}}$ & $N A^{h}$ & ND & ND & ND \\
\hline 8 & & 2.6 & 139.5 & 53 & 80 & 100 & 100 \\
\hline 9 & & 2.6 & 64.1 & 25 & 80 & 100 & 100 \\
\hline 10 & & 41.0 & ND & NA & ND & ND & ND \\
\hline 11 & & $>100$ & ND & NA & ND & ND & ND \\
\hline 12 & & $>100$ & ND & NA & ND & ND & ND \\
\hline 13 & & $>100$ & ND & NA & ND & ND & ND \\
\hline
\end{tabular}


14<smiles>Cc1ccc(Nc2nc(-c3ccccc3)cs2)cc1</smiles>

$>100$

ND

NA

ND

ND

ND

15<smiles>Fc1ccc(Nc2nc(-c3ccccc3)cs2)cc1</smiles>

$>100$

ND

NA

ND

ND

ND

16<smiles>COc1ccc(Nc2nc(-c3cccnc3)cs2)cc1</smiles>

81.2

ND

NA

$<10$

96

96

17<smiles>COc1ccc(Nc2nc(-c3ccncc3)cs2)cc1</smiles>

$>100$

ND

NA

10

98

83

18

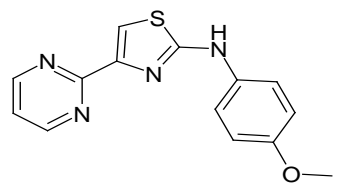

$51.1 \quad$ ND NA

40

81

99

Miltefosine $^{\mathrm{i}}$

8.2

54.1

17

The ${ }^{\mathrm{c} S e l e c t i v i t y ~ I n d e x ~(S I) ~ i s ~ d e f i n e d ~ a s ~ t h e ~ r a t i o ~ o f ~}{ }^{\mathrm{b}} \mathrm{CC}_{50}$ on $\mathrm{KB}$ cells to ${ }^{\mathrm{a}} \mathrm{IC}_{50}$ on L. donovani intracellular amastigotes.

$\mathrm{IC}_{50}\left(50 \%\right.$ inhibitory concentration) and $\mathrm{CC}_{50}(50 \%$ cytotoxic concentration) values are the average of two independent experiments carried out in duplicate (SD $\pm 10 \%)$.

${ }^{\mathrm{d}}$ Expressed as percentage of compound metabolized after 30 min of incubation.

${ }^{\mathrm{e} H a m L M}$, hamster liver microsome;

${ }^{\mathrm{f}} \mathrm{MLM}$, mouse liver microsome.

${ }^{\mathrm{g}} \mathrm{ND}$, not done.

${ }^{\mathrm{h}} \mathrm{NA}$, not available.

${ }^{\mathrm{i}}$ Miltefosine was used as a reference drug.

1

\section{Table 2:}

\begin{tabular}{ccccc}
\hline $\begin{array}{c}\text { Dose } \\
(\mathbf{m g} / \mathbf{k g})\end{array}$ & Route & $\begin{array}{c}\mathbf{T}_{\max } \\
\mathbf{( h )}\end{array}$ & $\begin{array}{c}\mathbf{C}_{\max } \\
(\mathbf{n g} / \mathbf{m L})\end{array}$ & $\begin{array}{c}\text { AUC } \\
(\mathbf{n g} . \mathbf{h} / \mathbf{m L})\end{array}$ \\
\hline 50 & Oral & 0.25 & 107.85 & 99.83 \\
\hline
\end{tabular}

Vehicle: Tween ${ }^{\circledR}$ 80: ethanol: water (7:3:90 v/v/v) 
Table 3:

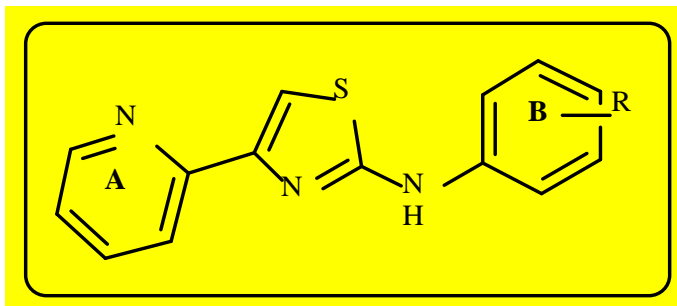

\begin{tabular}{|c|c|c|c|c|c|c|c|}
\hline \multirow{2}{*}{ Compd. } & \multirow{2}{*}{ Chemistry } & \multirow{2}{*}{$\begin{array}{l}I_{50}{ }^{a} \\
(\mu \mathrm{M})\end{array}$} & \multirow{2}{*}{$\begin{array}{l}\mathrm{CC}_{50}^{\mathrm{b}} \\
(\mu \mathrm{M})\end{array}$} & \multirow{2}{*}{$\mathbf{S I}^{\mathrm{c}}$} & \multirow{2}{*}{$\begin{array}{l}\text { Solubility } \\
\quad(\mu \mathrm{M})\end{array}$} & \multicolumn{2}{|c|}{ Metabolic Stability } \\
\hline & & & & & & HamLM $^{\mathrm{e}}$ & MLM \\
\hline 19 & & 1.40 & $>400$ & $>283$ & 20 & 99 & 98 \\
\hline 20 & & 1.72 & 55.6 & 32 & 80 & 100 & 99 \\
\hline 21 & & 70.9 & $\mathrm{ND}^{\mathrm{g}}$ & $\mathrm{NA}^{\mathrm{h}}$ & ND & ND & ND \\
\hline 22 & & 11.2 & 51.2 & 25 & ND & ND & ND \\
\hline 23 & & 0.37 & 12.4 & 34 & ND & ND & ND \\
\hline 24 & & 18.1 & 62 & 3 & 10 & 100 & 100 \\
\hline & osine $e^{i}$ & 8.2 & 54.1 & 17 & - & - & - \\
\hline
\end{tabular}

The ${ }^{\mathrm{c}}$ Selectivity Index (SI) is defined as the ratio of ${ }^{\mathrm{b}} \mathrm{CC}_{50}$ on $\mathrm{KB}$ cells to ${ }^{\mathrm{a}} \mathrm{IC}_{50}$ on $L$. donovani intracellular amastigotes.

$\mathrm{IC}_{50}$ (50\% inhibitory concentration) and $\mathrm{CC}_{50}$ (50\% cytotoxic concentration) values are the average of two independent experiments done in duplicate wells ( $\mathrm{SD} \pm 10 \%$ ).

${ }^{\mathrm{d}}$ Expressed as percentage of compound metabolized after 30 min of incubation.

${ }^{\mathrm{e}} \mathrm{HamLM}$, hamster liver microsome.

${ }^{\mathrm{f}} \mathrm{MLM}$, mouse liver microsome.

${ }^{\mathrm{g}} \mathrm{ND}$, not done. 
${ }^{\mathrm{h}} \mathrm{NA}$, not available.

${ }^{\mathrm{i}}$ Miltefosine was used as a reference drug.

Table 4:

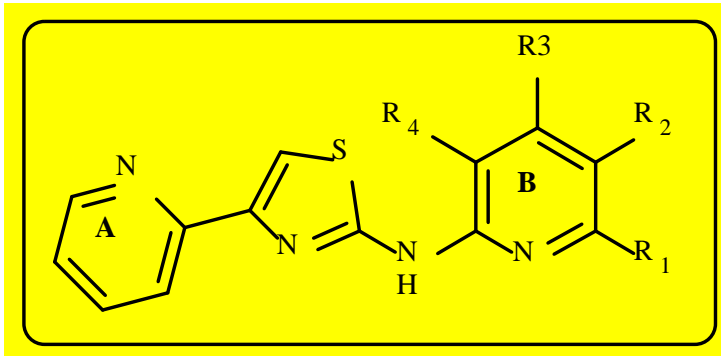

Compd.


30

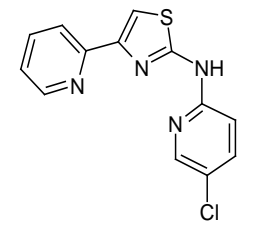

0.09

98.6

1096

$<10$

100

100

31

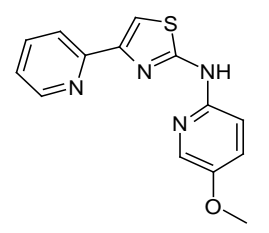

0.7

13.2

20

40

99

100

Miltefosine $^{\mathrm{i}}$

$8.2 \quad 54.1$

17

$-$

The ${ }^{\mathrm{c}}$ Selectivity Index (SI) is defined as the ratio of ${ }^{\mathrm{b}} \mathrm{CC}_{50}$ on $\mathrm{KB}$ cells to ${ }^{\mathrm{a}} \mathrm{IC}_{50}$ on $L$. donovani intracellular amastigotes.

$\mathrm{IC}_{50}\left(50 \%\right.$ inhibitory concentration) and $\mathrm{CC}_{50}(50 \%$ cytotoxic concentration) values are the average of two independent experiments done in duplicate wells ( $\mathrm{SD} \pm 10 \%$ ).

${ }^{\mathrm{d}}$ Expressed as percentage of compound metabolized after 30 min of incubation.

${ }^{\mathrm{e}}$ HamLM, hamster liver microsome.

${ }^{\mathrm{f}} \mathrm{MLM}$, mouse liver microsome.

${ }^{\mathrm{g}} \mathrm{ND}$, not done.

${ }^{\mathrm{h}} \mathrm{NA}$, not available.

${ }^{\mathrm{i}}$ Miltefosine was used as a reference drug. 


\section{Table 5:}

Compd.

The ${ }^{\mathrm{c}}$ Selectivity Index (SI) is defined as the ratio of ${ }^{\mathrm{b}} \mathrm{CC}_{50}$ on $\mathrm{KB}$ cells to ${ }^{\mathrm{a}} \mathrm{IC}_{50}$ on $L$. donovani intracellular amastigotes.

$\mathrm{IC}_{50}\left(50 \%\right.$ inhibitory concentration) and $\mathrm{CC}_{50}(50 \%$ cytotoxic concentration) values are the average of two independent experiments done in duplicate wells ( $\mathrm{SD} \pm 10 \%$ ).

${ }^{\mathrm{d}}$ Expressed as percentage of compound metabolized after 30 min of incubation.

${ }^{\mathrm{e}} \mathrm{HamLM}$, hamster liver microsome.

${ }^{\mathrm{f}} \mathrm{MLM}$, mouse liver microsome.

${ }^{\mathrm{g}} \mathrm{ND}$, not done.

${ }^{\mathrm{h}} \mathrm{NA}$, not available.

${ }^{\mathrm{i}}$ Miltefosine was used as a reference drug. 
Table 6:

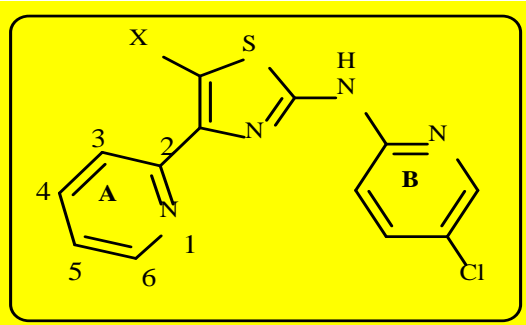

\begin{tabular}{|c|c|c|c|c|c|c|c|}
\hline \multirow{2}{*}{ Compd. } & \multirow{2}{*}{ Chemistry } & \multirow{2}{*}{$\begin{array}{l}\mathrm{IC}_{50}{ }^{\mathrm{a}} \\
(\mu \mathrm{M})\end{array}$} & \multirow{2}{*}{$\begin{array}{l}\mathrm{CC}_{50}^{\mathrm{b}} \\
(\mu \mathrm{M})\end{array}$} & \multirow{2}{*}{$\mathbf{S I}^{\mathrm{c}}$} & \multirow{2}{*}{$\begin{array}{l}\text { Solubility } \\
\quad(\mu \mathrm{M})\end{array}$} & \multicolumn{2}{|c|}{ Metabolic Stability } \\
\hline & & & & & & HamLM $^{\mathrm{e}}$ & MLM $^{\mathrm{f}}$ \\
\hline 30 & & 0.09 & 98.6 & 1096 & $<10$ & 100 & 100 \\
\hline 37 & & 0.06 & 326 & 5433 & $<10$ & 100 & 93 \\
\hline 38 & & 0.01 & 15 & 1500 & $<10$ & 100 & 90 \\
\hline 39 & & 0.02 & 248 & 12400 & $<10$ & 100 & 92 \\
\hline 40 & & 4.23 & $>400$ & $>95$ & $<10$ & 63 & 30 \\
\hline 41 & & 1.72 & 12.1 & $>7$ & $<10$ & 87 & 56 \\
\hline & fosine $e^{g}$ & 8.2 & 54.1 & 17 & - & - & - \\
\hline
\end{tabular}

The 'Selectivity Index (SI) is defined as the ratio of ${ }^{b} \mathrm{CC}_{50}$ on $\mathrm{KB}$ cells to ${ }^{\mathrm{a}} \mathrm{IC}_{50}$ on L. donovani intracellular amastigotes.

IC $_{50}\left(50 \%\right.$ inhibitory concentration) and $\mathrm{CC}_{50}$ (50\% cytotoxic concentration) values are the average of two independent experiments done in duplicate wells ( $\mathrm{SD} \pm 10 \%$ ).

${ }^{\mathrm{d}}$ Expressed as percentage of compound metabolized after 30 min of incubation.

${ }^{\mathrm{e}} \mathrm{HLM}$, hamster liver microsome.

${ }^{\mathrm{f}} \mathrm{MLM}$, mouse liver microsome

${ }^{\mathrm{g}}$ Miltefosine was used as a reference drug. 


\section{Table 7:}

\begin{tabular}{|c|c|c|c|c|c|c|c|c|}
\hline $\begin{array}{c}\text { Dose } \\
\text { (mg/kg) }\end{array}$ & $\begin{array}{c}T_{\max } \\
\text { (h) }\end{array}$ & $\begin{array}{c}\mathrm{C}_{\max }^{\mathrm{a}} \\
(\mathrm{ng} / \mathrm{mL})\end{array}$ & $\begin{array}{c}\mathrm{AUC}_{\text {last }}^{\mathrm{b}} \\
\text { (ng.h/mL) }\end{array}$ & $\begin{array}{c}\text { AUC }_{\text {inf }} \\
\text { (ng.h/mL) }\end{array}$ & $\begin{array}{l}T_{1 / 2} \\
\text { (h) }\end{array}$ & $\begin{array}{c}\mathrm{CL} \\
(\mathrm{mL} / \mathrm{min} / \mathrm{kg})\end{array}$ & $\begin{array}{c}V_{\text {ss }} \\
(\mathrm{L} / \mathrm{kg})\end{array}$ & $\mathbf{F}^{\mathbf{C}}$ \\
\hline $\begin{array}{c}1 \\
\text { (IV solution) }\end{array}$ & $\mathrm{NA}^{\mathrm{d}}$ & 884.66 & 177.96 & 183.17 & 0.48 & 90.99 & 1.99 & \\
\hline $\begin{array}{c}25 \\
\text { (PO } \\
\text { suspension) }\end{array}$ & 0.25 & 167.30 & 361.79 & 377.40 & NA & NA & NA & 8 \\
\hline
\end{tabular}

aback-extrapolated concentration.

${ }^{\mathrm{b}}$ AUC, area under the concentration time curve.

${ }^{\mathrm{C}} \mathrm{AUC} \mathrm{C}_{\text {inf }}$ and nominal doses were used for absolute bioavailability (F) calculation.

${ }^{\mathrm{d}} \mathrm{NA}$, not applicable.

Regression points selected for estimation of elimination rate constant were $0.5,1$ and $2 \mathrm{~h}$.

Vehicle IV: 10\% (v/v) 1-methyl-2-pyrrolidinone, 10\% (v/v) Cremophore EL, 10\% (v/v) Propylene glycol, Normal Saline q. s., PO: Tween ${ }^{\circledR} 80$ : Ethanol: water $(7: 3: 90 \mathrm{v} / \mathrm{v} / \mathrm{v})$. 
Table 8:

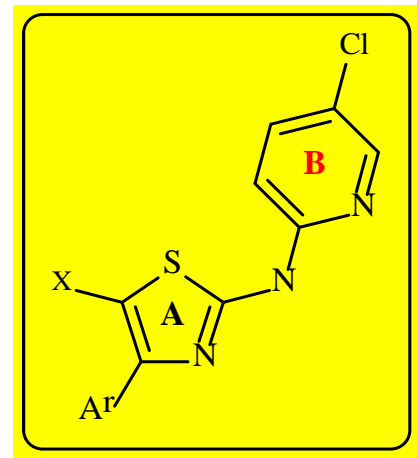

\begin{tabular}{|c|c|c|c|c|c|c|c|}
\hline \multirow{2}{*}{ Compd. } & \multirow{2}{*}{ Chemistry } & \multirow{2}{*}{$\begin{array}{l}\mathrm{IC}_{50}^{\mathrm{a}} \\
(\mu \mathrm{M})\end{array}$} & \multirow{2}{*}{$\begin{array}{l}\mathrm{CC}_{50}{ }^{\mathrm{b}} \\
(\mu \mathrm{M})\end{array}$} & \multirow{2}{*}{$\mathbf{S I}^{\mathrm{c}}$} & \multirow{2}{*}{$\begin{array}{l}\text { Solubility } \\
\quad(\mu \mathrm{M})\end{array}$} & \multicolumn{2}{|c|}{ Metabolic Stability } \\
\hline & & & & & & HamLM $^{\mathrm{e}}$ & MLM $^{\mathrm{f}}$ \\
\hline 42 & & 1.73 & 10.28 & 6 & 20 & 99 & 95 \\
\hline 43 & & 5.82 & 28.08 & 5 & $<10$ & 99 & 70 \\
\hline 44 & & 1.54 & 20.71 & 13 & 20 & 100 & 99 \\
\hline 45 & & 0.16 & 66.12 & 413.2 & $<10$ & 99 & 71 \\
\hline 46 & & 37.5 & $\mathrm{ND}^{\mathrm{g}}$ & $\mathrm{NA}^{\mathrm{h}}$ & $<10$ & 99 & 99 \\
\hline 47 & & 95.0 & 3.17 & 0.03 & $<10$ & 78 & 47 \\
\hline 48 & & $>100$ & 20.24 & 0.20 & $<10$ & 100 & 100 \\
\hline & fosine $e^{i}$ & 8.2 & 54.1 & 17 & - & - & - \\
\hline
\end{tabular}

The ${ }^{\mathrm{c}}$ Selectivity Index (SI) is defined as the ratio of ${ }^{\mathrm{b}} \mathrm{CC}_{50}$ on $\mathrm{KB}$ cells to ${ }^{\mathrm{a}} \mathrm{IC}_{50}$ on $L$. donovani intracellular amastigotes. 
$\mathrm{IC}_{50}$ (50\% inhibitory concentration) and $\mathrm{CC}_{50}(50 \%$ cytotoxic concentration) values are the average of two independent experiments done in duplicate wells ( $\mathrm{SD} \pm 10 \%)$.

${ }^{\mathrm{d}}$ Expressed as percentage of compound metabolized after 30 min of incubation.

${ }^{\mathrm{e}} \mathrm{HLM}$, hamster liver microsome.

${ }^{\mathrm{f}} \mathrm{MLM}$, mouse liver microsome.

${ }^{g} \mathrm{ND}$, not done.

${ }^{\mathrm{h}} \mathrm{NA}$, not available.

${ }^{\mathrm{i}}$ Miltefosine was used as a reference drug. 
Figure 1:

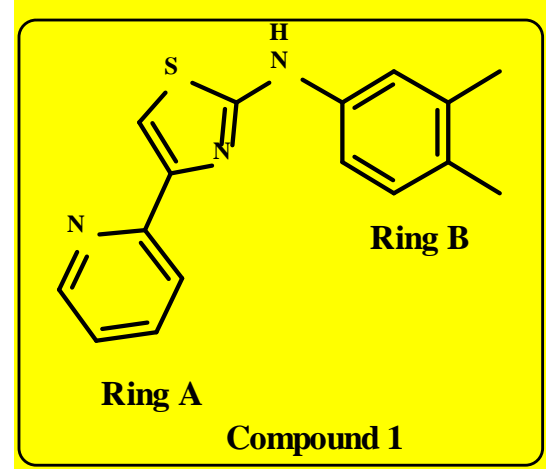

Figure 2:

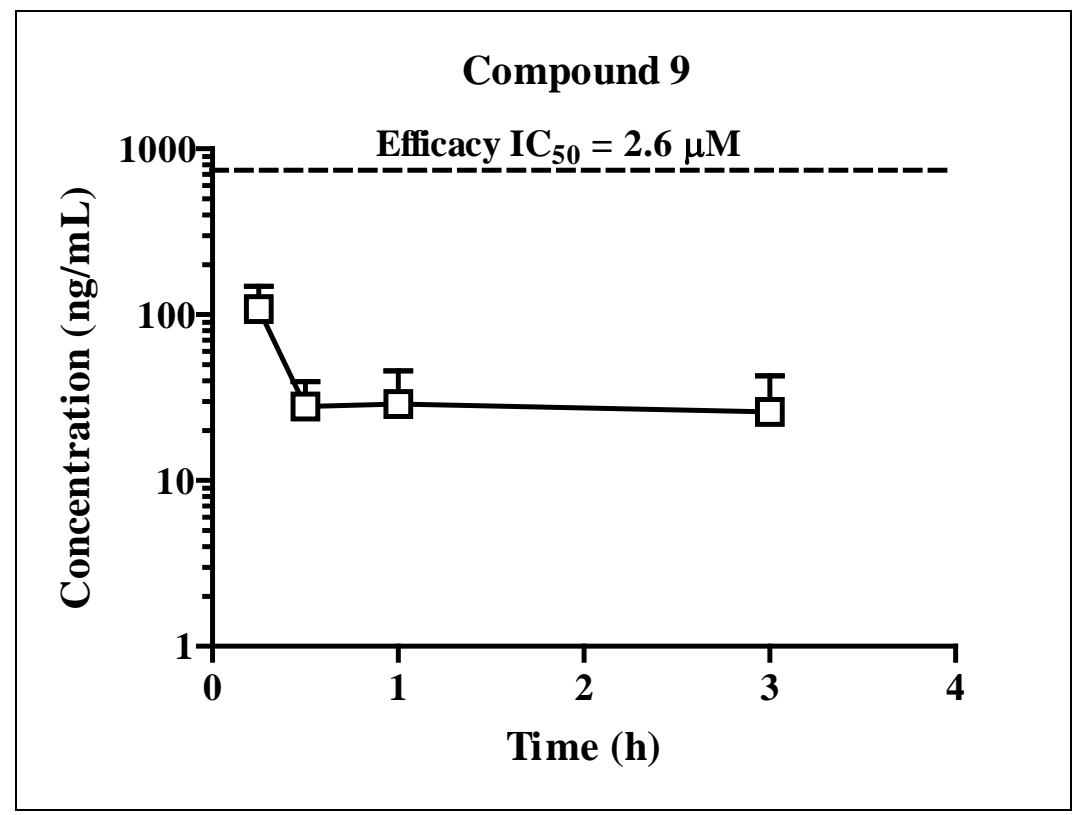


Figure 3:

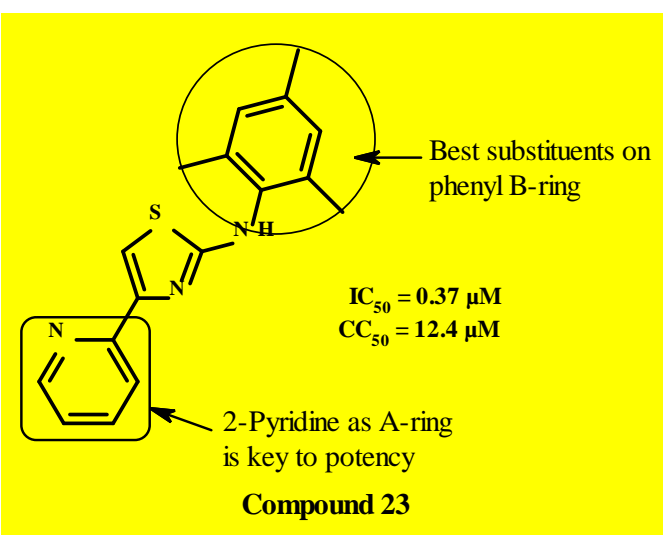

Figure 4:

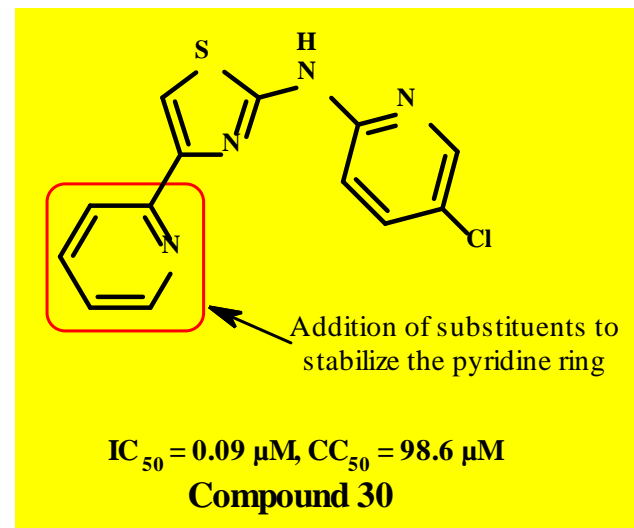

Figure 5:
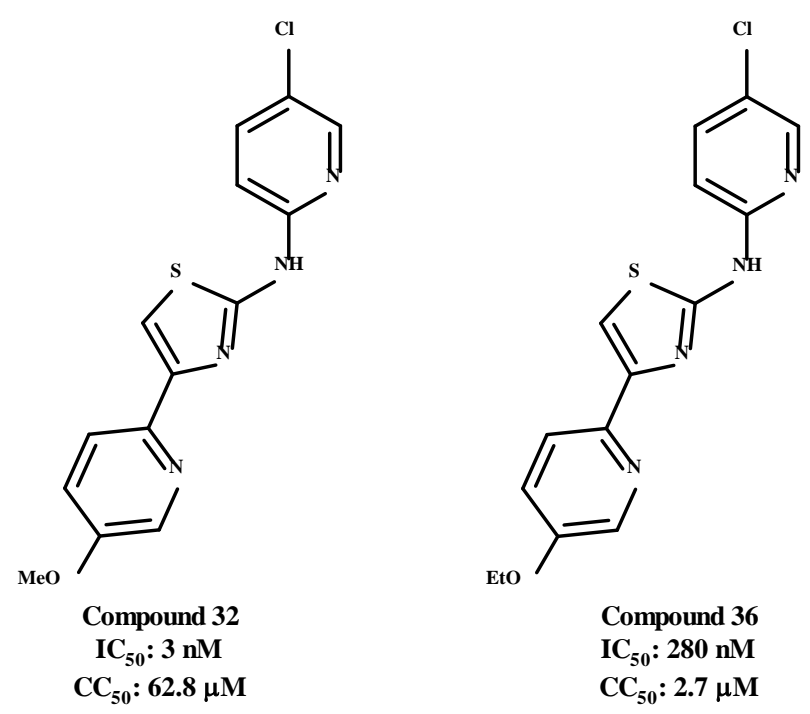


\section{Figure 6:}

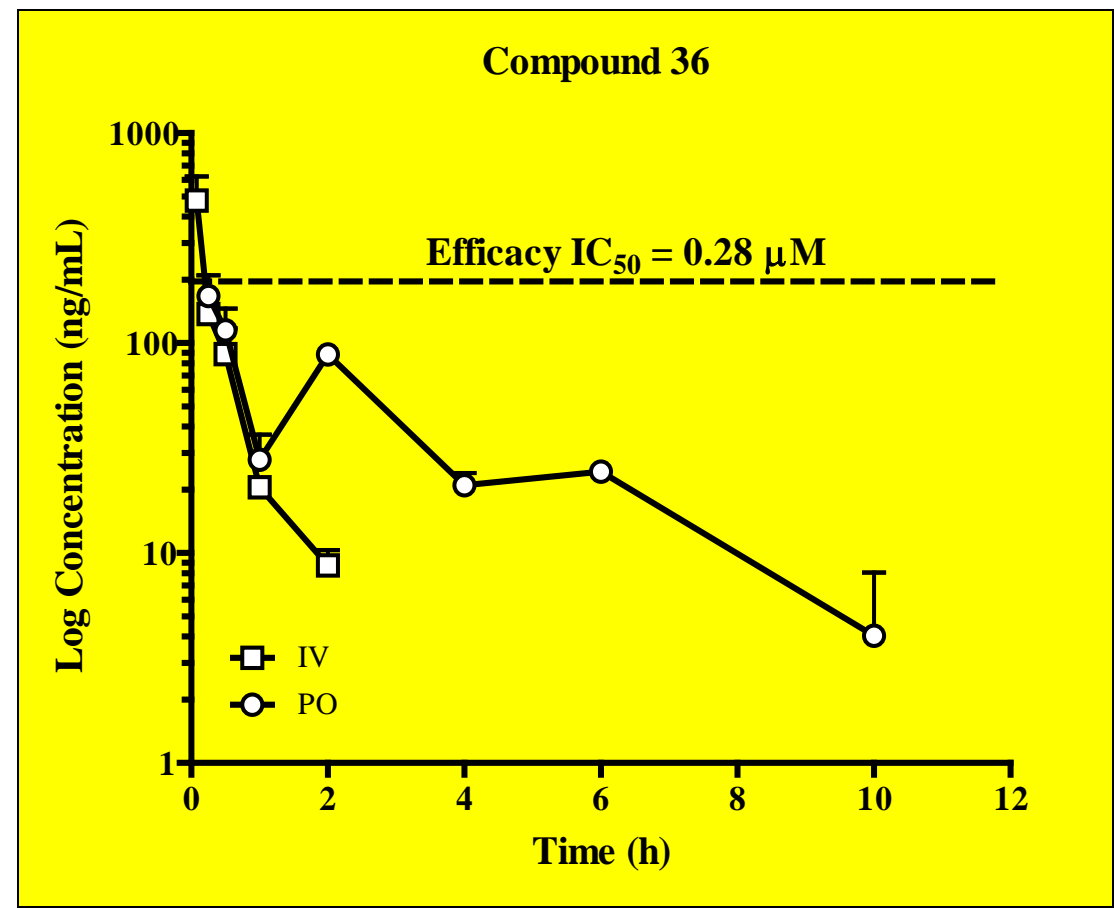

\section{Scheme 1:}

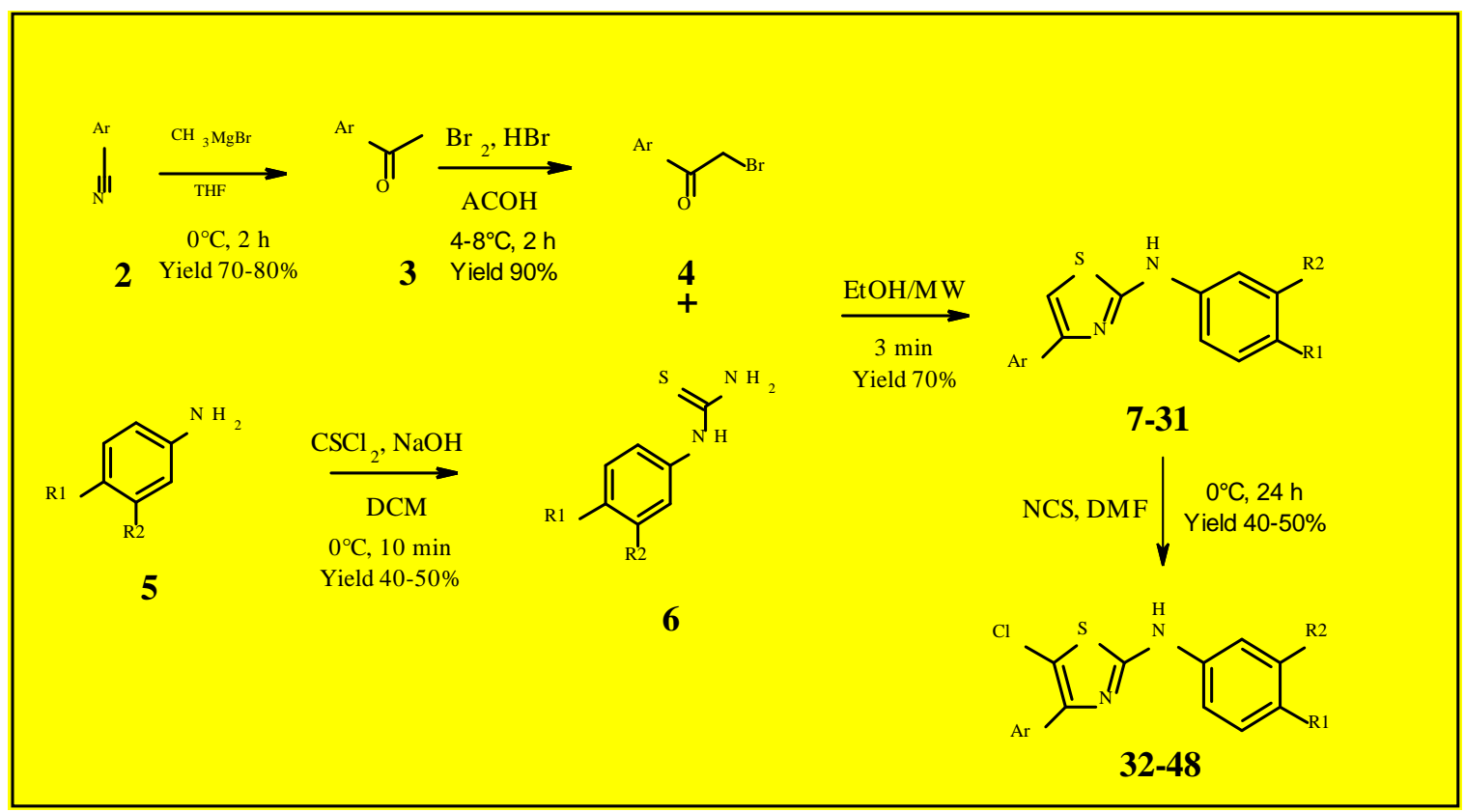

